\title{
DESIGN OF NOVEL BIODRYING PROCESS FOR PULP AND PAPER MILL SLUDGE, AND IMPACT ON FLUIDIZED BED BOILER EFFICIENCY
}

Tchoryk, C.; Paul Stuart, P.R.

NSERC Environmental Design Engineering Chair, Department of Chemical Engineering, Ecole Polytechnique, Quebec, Canada paul.stuart@polymtl.ca

\section{INTRODUCTION}

It is widely used practice in the pulp and paper industry to burn its waste water sludge after mechanical dewatering as it allows the recovery of energy and reduces landfilling [1]. However, the sludge's low dryness has a big impact on the energy recovered from the boiler [3,5]. A novel biodrying process is evaluated as a solution to add value to the sludge.

In biodrying, heat is produced by the exothermic metabolism of microorganisms present in the sludge. Aeration of the biological material serves two purposes; keeping microorganisms in an aerobic state and removing water from the system. Biodrying is similar to composting, but has a different goal; where composting looks at degrading biological matter; biodrying looks at maximizing the low heating value

The goal of this study was to assess the economic viability of a vertical continuous biodrying process. This was done by showing the economic benefits of the process in a pulp and paper mill and by demonstrating that full scale operation can be attained based on pilot plant experiments. This study required a variety of skills essential for process engineers. This paper will show the importance of multidisciplinary that can be found in a chemical engineering master's degree project.

\section{METHOD}

The first step of the study was the commissioning of a novel vertical continuous biodryer. Unforeseen difficulties had to be worked out with the pilot plant. The first main issue encountered was an uneven sludge residence time that caused gaps and bridging. This was resolved by re-engineering the discharge screw. The second issue was the condensation of moisture before and on measurement instruments from air exiting the dryer. Better insulation and heating were installed to remediate this. Large volumes of sludge, limited storage area, and long experimental runs of 8 to 12 days, required management skills. Logistics were needed to coordinate experiment scheduling and sludge shipping from and to a pulp and paper mill.

With the results from the experiments, an empirical model was created to predict sludge characteristics based on dryer operating conditions. Scale-up of the process was done using basic experimental data analysis and comparing the new process with similar industrial processes, either other biodrying designs [4,2] or in-reactor composting, The data for this comparison originated mostly from the grey literature, such as companies' website.

Table 1: Summary of case study mills

\begin{tabular}{cccc}
\hline $\begin{array}{c}\text { Case study } \\
\text { mill }\end{array}$ & 1 & 2 & 3 \\
\hline Fuel burned & $\begin{array}{c}\text { Bark } \\
\text { Bunker C } \\
\text { Sludge }\end{array}$ & $\begin{array}{c}\text { Bark } \\
\text { Sludge }\end{array}$ & $\begin{array}{c}\text { Bark } \\
\text { Bunker C }\end{array}$ \\
Notes & No fossil fuel & $\begin{array}{c}\text { Sludge is } \\
\text { landfilled }\end{array}$ \\
\hline
\end{tabular}

As in most of the mills studied, sludge was burned in a fluidized bed boiler with other fuels; a fluidized bed boiler model was developed in close collaboration with an industrial partner in order to obtain information on boiler operations. For instance, the effect of moisture on the fluidized bed boiler needed to be characterized for the development of this model. This technical model was integrated with a cost model for the operating and capital costs in order to obtain a techno-economic model. The techno-economic model needed to take into account both dryer and boiler operations. Technoeconomic analyses were done for three case study mills. Rotary dryers using a natural gas burner were compared to the biodryer for those case studies, to assess the biodryer's competivity with that of more establish technologies.

\section{RESULTS}

The experiments showed a good potential for the continuous vertical biodryer. A temperature of over $70^{\circ} \mathrm{C}$ was obtained inside the bed. Also, for a residence time of 4 days, the dryness of the sludge went from $36,5 \%$ to $45.0 \%$. Due to transport and storing in a cold room of the sludge during trials, better results would be expected of hot and acclimated sludge used at a mill site in a full scale process.

As can be seen on figure 1, results from case 3 showed that the continuous biodrying process could have a return on investment of less than 2 years and have a return similar to the rotary dryer.

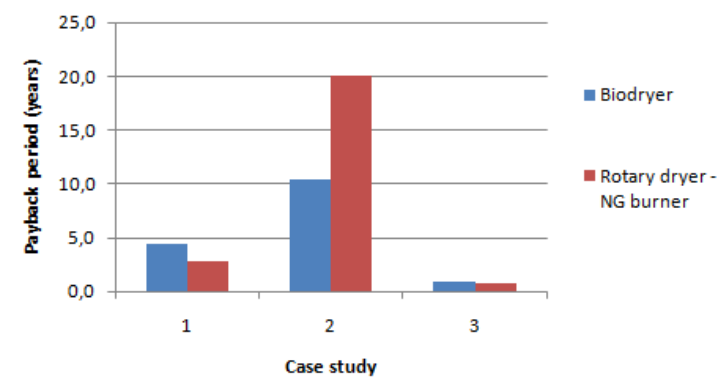

Figure 1: Payback period for case study mills

DISCUSSION

Interaction with industrial partners expanded the original boundaries of the study by looking at environmental aspects and interaction with the mills' other operations and the understanding of the mills' layout for possible implementation. This shows how a master's degree project in engineering needs skills in time management, experimentation, technical and economic modeling, and analysis.

\section{REFERENCES}

[1] Pulp and Paper Sludge to Energy - Preliminary Assessment of Technologies. CANMET Energy Technology Center; 2005.

[2] Navaee-Ardeh, S., Bertrand, F., Stuart, P.R. Emerging biodrying technology for the drying of pulp and paper mixed sludges. Drying Technology. 2006;24:863-878.

[3] Suksankraisorn, K., Patumsawad, S., Fungtammasan, B. Combustin studies of high moisture content waste in a fluidised bed. Waste Management. 2003;23:433-439. [4] Velis C.A, Longhurst P.J., Drew G.H, Smith R., Pollard, S.J.T. Biodrying for mechanical-bioogical treatment of wastes: A review of process science and engineering. Bioresource Technology.2009; 100: 2747-2761. [5] Woodfield, P.L., Kent, J.H., Dixon, T.F. Computational modelling of combustion instability in bagasse-fired furnaces. Experimental Thermal and Fluid Science. 2000;21:17-25. 